\title{
3D GIDA BASKISI: GÜNCEL DURUM VE GELECEK EĞİLİMLERİ
}

\author{
Kezban Candoğan*, Elvan Gökçen Bulut \\ Ankara Üniversitesi, Mühendislik Fakültesi, Gıda Mühendisliği Bölümü, 06830, Ankara, Türkiye \\ Geliş / Received: 09.10.2020; Kabul / Accepted: 24.12.2020; Online bask1 / Published online: 04.01.2020
}

Candoğan, K., Bulut, E.G. (2021). 3D gida baskısı: güncel durum ve gelecek eğilimleri. GIDA (2021) 46(1) 152-167 doi: 10.15237/gida. GD20130.

Candoğan, K., Bulut, E.G. (2021). 3D foodprinting: an update and future trends. GIDA (2021) 46(1) 152-167 doi: $10.15237 /$ gida. GD20130.

\section{ÖZ}

3D gıda baskısı, ilgi çekici ve özgün özelliklere sahip özel amaca yönelik gıda üretiminde şekil, boyut, doku ve lezzet açısından istenilen özellikleri sağlayabilen yeni gıda tasarımını mümkün kılan bir teknoloji olarak ortaya çıkmıştır. Gıda pazanında, farklı ihtiyaçlara hizmet eden, bir kısmı evlerde kullanıma uygun; bir kısmı ise endüstriyel üretimde yüksek verimlilik ve otomasyonu mümkün kılan gelişmiş, çok amaçlı 3D gida yazıcıları bulunmaktadır. 3D gıda baskı teknolojisi, israfi ve işçilik maliyetlerini en aza indirerek enerji tasarrufu sağlar ve üretim hattna kolay entegre edilebilir özelliktedir. Yaşllar, çocuklar ve sağllk sorunları nedeniyle diyetleri kısıtlanan bireyler bu teknolojiden yararlanan özel tüketici gruplarıdır. Günümüz tüketicilerinin ihtiyaçlannı karşılamada geleneksel üretim yaklaşımlanna kıyasla daha üstün kalitede ve düşük maliyetle ürünler sunduğu için 3D gıda baskısının gida endüstrisinde umut vadeden bir geleceği olduğu bir gerçektir. Bu derlemede, 3D gida baskısının prensipleri ve uygulamaları ile mevcut 3D gida yazıcıları hakkında bilgilere yer verilmiştir. Bu teknolojinin olumlu ve olumsuz yanları tartş̧ılmış, güncel araştırmalar ve olası uygulamalar hakkında bilgi verilmiş ayrıca, 3D gıda baskısı ile üretilen gıda ürünlerine yönelik tüketici tutumlanı özetlenmiştir.

Anahtar Kelimeler: 3D gıda baskısı, 3D gıda yazıcıları, gıda tasarımı, kişiye özel gıda

\section{D FOOD PRINTING: AN UPDATE AND FUTURE TRENDS}

\begin{abstract}
3D Food Printing has emerged as viable tool to manufacture personalized food products in small or large quantities. This technology has interesting and unique features such as the formulation of food products with high repeatability in terms of desirable shape, size, texture and flavor. There are a number of $3 \mathrm{D}$ food printers that have been designed to fulfill a wide spectrum of needs within the food market. Some of these printers are very simple and could be even used in households where others are quite sophisticated, very versatile, fully automized, and with variable throughput. 3D food printing minimizes waste and labor costs, facilitates energy savings and could be easily integrated in a production line. Elderly, children, people with restricted diets because of health issues are among the consumer groups that are particularly benefited by this technology. It is quite apparent that 3D food printing has a bright future within the food industry because it facilitates addressing the needs of today's consumers while offering products of superior quality and lower costs to those manufactured by more traditional approaches. This overview includes principles and applications of
\end{abstract}

\footnotetext{
*Yazışmalardan sorumlu yazar / Corresponding author

Al candogan@eng.ankara.edu.tr, (1): (+90) 3122033300
}

冝: (+90) 3123178711

Kezban Candoğan; ORCID no: 0000-0002-6721-8835

Elvan Gökçen Bulut; ORCID no: 0000-0002-1468-0292 
3D food printing and currently available 3D food printers. Pros and cons of this technology are discussed and an update on recent research and potential implementation are provided. Consumer attitudes towards food products manufactured by 3D food printing are also summarized.

Keywords: 3D food printing, 3D food printers, food design, customized food

\section{GİRİ̧̧}

Günümüzde bilim ve teknolojide meydana gelen gelişmeler, gida sektörünü de etkilemiş ve sektörde hızla ortaya çıkan değişimler gerek üretici gerekse tüketici açısından farklı arayışların ortaya çıkmasına neden olmuştur. Bir yandan tüketicilerin yaşam kalitesini iyileştirme, her şeyin en güzelini tüketme arzusu ve konfor arayışı, diğer yandan, gida üreticilerinin bu yönde ortaya çıkan farklı lezzette, albenili, kısa zamanda hazırlanan ve aynı zamanda sağlıklı gıdalara olan talebi karşılama yönündeki çabaları, gida teknolojistlerini yeni ürün arayışlarına yöneltmiştir (Bakan vd., 2011; Sezer ve Taş, 2012; Bulut, 2019). Bu kapsamda, tüketicinin istek ve ihtiyaçları doğrultusunda, kişiye özel yeni gida ürünleri üretimini amaç edinen "gıda tasarımı" olgusu son yıllarda yenilikçi teknolojilere olan gereksinimi artırmıştır. Küreselleşmeyle birlikte yaygınlaşan ve gündelik yaşamımızı önemli ölçüde değiştiren yenilikçi uygulamalar içerisinde önemli bir yer tutan dijital teknolojiler, diğer birçok sektörde olduğu gibi g1da sektöründe de uygulama alanı bulmuştur (Yang vd., 2015). Bu kapsamda ortaya çıkan, farklı amaçlar için gıda tasarımında kullanılabilen üç boyutlu (3D) gıda baskısı, yenilikçi ve karmaşık gıda ürünlerini çekici bir biçimde sunabilen geleceğin popüler teknolojilerinden biridir.

İlk kez 1984 yllında Charles Hull tarafindan kullanılmış olan 3D baskı teknolojisi, "Nanotek Instruments" firması tarafindan geliştirilen 3D gida üretimi için bir prototipin patenti alınmasıyla 2001 yılında gida sektöründe yerini almıştır (Hull, 1984; Whitaker, 2014; Sun vd., 2015a; Sun vd., 2015c). Daha sonra özellikle son beş yılda üzerinde yapılan araştırmaların hızla arttığ $3 \mathrm{D}$ gıda baskısı gelecek nesiller için bir "yazdır-ye" (print-and-eat) teknolojisi olarak kabul edilmektedir (Prakash vd., 2019).

Geleneksel üretim yöntemleri ile kıyaslandığında daha az atık oluşturması, hızlı prototip ürünler oluşturulabilmesi, zamandan ve üretim sırasında enerjiden tasarruf sağlaması, basit üretim prosesine sahip olması gibi avantajlarından dolayı 3D gida baskısı geleceğin iddialı teknolojilerinden biri olarak görülmektedir (Berman vd., 2012; Yang vd., 2015; Nachal vd., 2019). Son yillarda tüm dünyada 3D gida yazıcılarının kullanıldığı çeşitli bask1 denemelerinin gerçekleştirildiği çalışmalar hızla devam etmektedir. Bu çalışmada, 3D gida baskısında kullanılan teknolojiler avantaj ve dezavantajlarıyla ele alınmış, 3D gida yazıcılarının mevcut kullanımı ile gelecek eğilimleri ve yeni bir kavram olan 4D gida bask1 teknolojisi bu konudaki güncel literatür değerlendirilerek tartışılmıstır.

\section{D GIDA BASKISI VE 3D GIDA YAZICILARININ MEVCUT DURUMU}

İstenen formda, lezzette, şekilde, boyutta ve kişiselleştirilebilen yeni ürünler tasarlamak için kullanılan 3D gida baskıs1, bilgisayar destekli yeni bir üretim yaklaşımıdır. Genel olarak modelleme, dilimleme ve yazdırma olmak üzere üç temel basamaktan oluşan 3D bask1 işlemi gerçekleştirilirken ilk olarak bastırlmak istenen nesne bilgisayar destekli tasarım yazılımı (Solidworks, Tinkercad, Catia vb.) ile tasarlanmakta ve 3D modelleme STL (stereolitografi) formatına dönüştürülmektedir (Arlı ve Demirbaş, 2015; Ötleş, 2016). STL formatının 3D yazıcı tarafindan anlaşılabilir hale getirilmesi için dilimleme işlemi gerekir. Dilimleme işlemi G-code denilen programlama dili vasıtası ile gerçekleştirilir. Gcode, adım adım yazıcıdaki eksenlerin nasil hareket etmesi gerektiğini belirleyen kodlardan oluşur. G-code işleminden sonra yazıcı alınan verilere göre her tabakayı üst üste inşa ederek ürünün bask1s1 yapılır (Feng vd., 2015; Pallottino vd., 2016).

3D bask1 işlemi, bilgisayarda hazırlanmış dijital veriyi kullanarak yazıcı kartuşu içerisine yerleştirilen malzemenin katmanli biriktirilmesi prensibine dayanır (Yang vd., 2015; Izdebska ve Zolek-Tryznowska, 2016). Bastırlacak gidanın yapısına bağlı olarak 3D gida yazıcılarının tasarlanmasında farklı baskı teknolojileri kullanılır 
(Şekil 1). Bu farklı teknolojilerle çalışan gida yazıcılarının besleme kaynağı türü, kullanılan teknikler, çalısma prensibi, bağlama mekanizması ve bu tekniklerin bazı kullanım alanları Çizelge 1 'de verilmiştir.
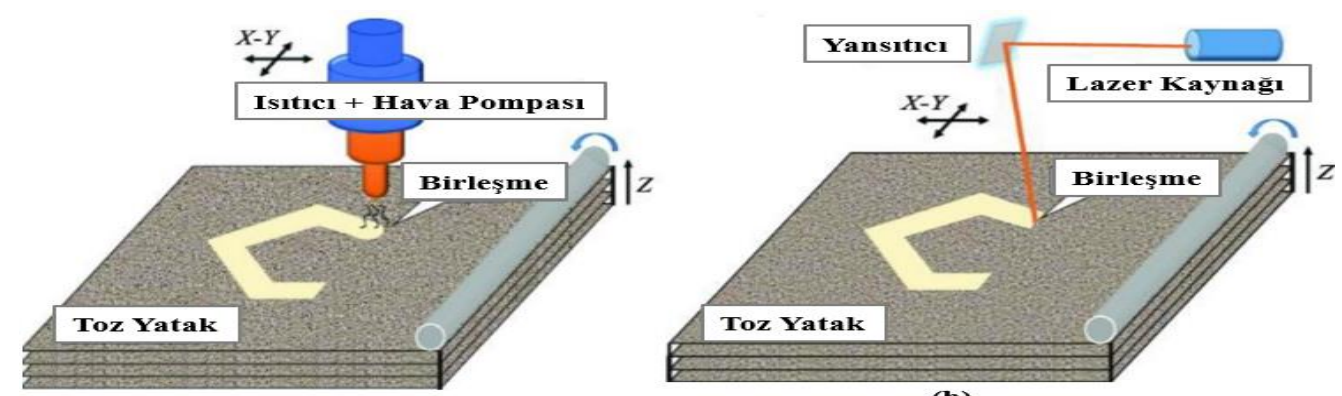

(a)

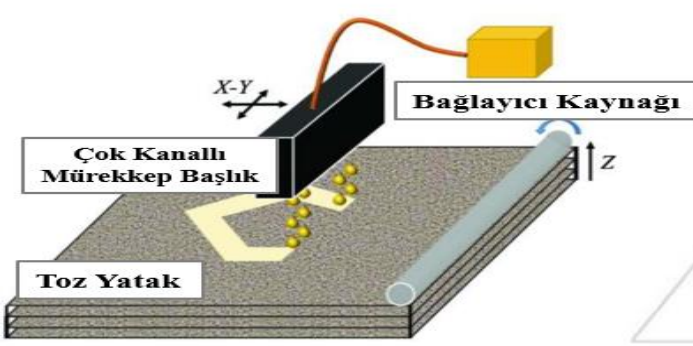

(c)

(d)

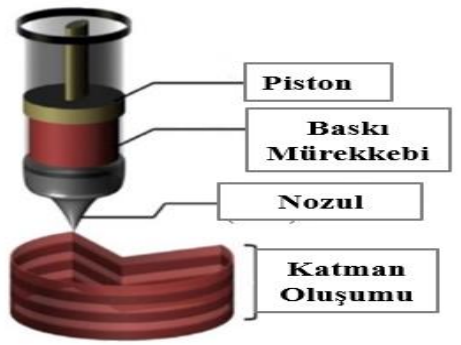

(e)

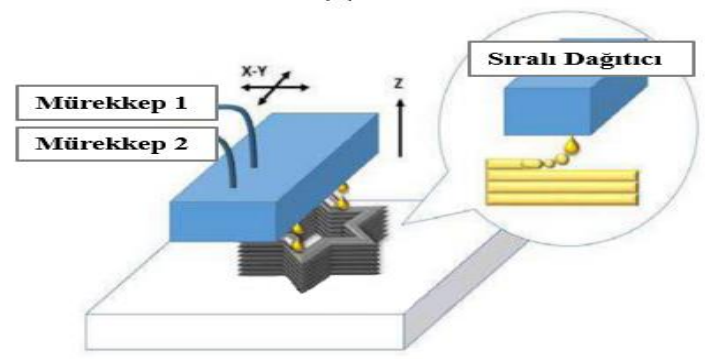

(f)

Şekil 1. 3D gida baskisinda uygulanan teknolojiler (Sun vd., 2015c; Godoi vd., 2016) (a) Sicak Hava Sinterleme (b) Selektif Lazer Sinterleme (c) Sıvı Bağlayıc1 (d) Erime Ekstrüzyon (e) Yumuşak Materyal Ekstrüzyon (f) Mürekkep Püskürtme

3D gida yazıcılarında kullanılan baskı teknolojisi, yazdırılabilecek gıda çeşitliliği, kullanım kolaylı̆̆ı, düşük maliyet gibi faktörler yazıcının tercih edilebilirliğini etkiler. Selektif lazer sinterleme, bağlayıcı püskürtme, mürekkep püskürtme ve ekstrüzyon 3D gida baskısında yaygın olarak kullanilan teknolojilerdir. Selektif lazer sinterleme (SLS) teknolojisinde, lazer kaynağı yardımıyla toz formundaki bir kartuş içeriğinin katmanlar halinde birikimi sağlanır ve 3D nesnelerin oluşumu gerçekleşir (Shellabear ve Nyrhila, 2004). İnsanların gida güvenliği kaygiları, lazer ve elektron demetine olan olumsuz bakış açısı bu teknolojinin 3D yazıcı ile gida üretimi konusunda kullanımını sinırlandırmaktadır (Liu ve Zhang, 2019). Selektif lazer ve sicak hava ile sinterleme işlemleri, üretim prosesi karmaşık olan gıdaları hızlı bir şekilde üretme avantajı sağlar. Bununla birlikte, bu teknolojiler sadece nispeten düşük erime noktasına sahip şeker ve yağ tabanlı malzemeler için uygundur. Makine yapısının yanı sıra imalat işlemlerinde de birçok değişken dahil olduğu için sistem karmaşıktır (Sun vd., 2015b). Bağlayıcı püskürtme teknolojisi, hızlı imalat ve düşük malzeme maliyeti gibi avantajlar sağlamakla birlikte, üretilen ürünün yüzeyinin pürüzlü olması ve yüksek makine maliyeti gibi dezavantajlara da sahiptir. Bu teknoloji ile albenili gidalar 
üretilebilmesine rağmen, elde edilen ürünler besin değeri düşük, şeker içeriği ise yüksek olduğu için diyabet, obezite ve kalp hastalığ1 ile ilişkilendirildiğinden sağllk için tehdit oluşturmakta, bu durum bağlayıcı püskürtme teknolojisinin pazar potansiyelini olumsuz yönde etkilemektedir (Sun vd., 2015b). Mürekkep püskürtmeli bask1 teknolojisi ile çalışan yazıcılar ise genellikle düşük viskoziteli materyalleri yazdırmak için kullanılır. Bask1 hassasiyeti ve doğruluğu açısından, mürekkep ve alt tabaka yüzeyi arasindaki uyumluluk, baskı materyalinin reolojik özellikleri, sıcaklık ve baskı hızı başarılı bir baskı için önemli faktörlerdendir. Karmaşık gidalann baskısında kullanılamaması bu teknolojinin en büyük dezavantajıdır (Liu vd., 2017). Ekstrüzyon temelli bask1 teknolojisi çikolata, jelatin, şeker gibi sıcaklık uygulandığında akışkan forma geçebilen gıdaların, püre, jel ve hamur halindeki materyallerin basımında kullanilabilmektedir (Yang vd., 2015). Doğrudan yazdırılamayan gidalara ksantan gam, jelatin, gam arabik, karragenan vb. hidrokolloidlerin ilavesi yapılarak ürün yapısı desteklenmekte ve şeklin deformasyonu önlenebilmektedir. Ayrıca, formülasyona enzim ilavesi yapilarak da yapının korunması sağlanabilir. Yang vd. (2015) hindi, kereviz ve deniztarağı bazlı üç ayrı formülasyona transglutaminaz enzimi ilave ederek 3D yazıcıda farklı şekillerde yazdırılan ürünlerde enzim ilavesinin pişirme sonrası yapının korunmasını sağladığını bildirmişlerdir.

Çizelge 1. 3D gida baskısında kullanılan teknikler (Godoi vd., 2016; Holland vd., 2018; Liu vd., 2018; Wang vd., 2018; Liu vd., 2019b; Warner vd., 2019)

\begin{tabular}{|c|c|c|c|c|}
\hline $\begin{array}{l}\text { Besleme } \\
\text { Kaynağ1 }\end{array}$ & $\begin{array}{c}\text { Kullanilan } \\
\text { Teknik } \\
\end{array}$ & Prensip & Bağlama Mekanizması & Kullanım Alanı \\
\hline \multirow{4}{*}{ 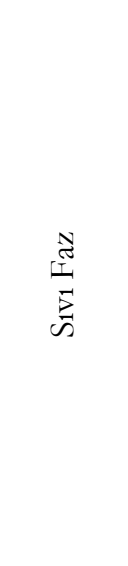 } & $\begin{array}{l}\text { Yumuşak } \\
\text { materyal } \\
\text { ekstrüzyon }\end{array}$ & $\begin{array}{l}\text { Ekstrüzyon ve } \\
\text { biriktirme }\end{array}$ & $\begin{array}{l}\text { Faz değissimi yok; } \\
\text { materyalin reolojik } \\
\text { özellikleriyle kontrol } \\
\text { edilen katmanlar }\end{array}$ & $\begin{array}{l}\text { Kek kreması, işlenmiş peynir, et } \\
\text { püresi, hamur, tuz ilaveli balık } \\
\text { surimi, soya yağ1/peyniraltı suyu } \\
\text { protein izolatı karışımı }\end{array}$ \\
\hline & $\begin{array}{l}\text { Erime } \\
\text { ekstrüzyonu }\end{array}$ & $\begin{array}{l}\text { Ekstrüzyon } \\
\text { ve biriktirme }\end{array}$ & Soğutma ile katılaşma & $\begin{array}{l}\text { Çikolata ve } \\
\text { şekerlemeler }\end{array}$ \\
\hline & $\begin{array}{l}\text { Hidrojel } \\
\text { ekstrüzyon }\end{array}$ & $\begin{array}{l}\text { Ekstrüzyon ve } \\
\text { biriktirme }\end{array}$ & $\begin{array}{l}\text { İyonik veya enzimatik } \\
\text { çapraz bağlanma }\end{array}$ & $\begin{array}{l}\text { Ksantan gam, jelatin, } \\
x \text {-karragenan }\end{array}$ \\
\hline & $\begin{array}{l}\text { Mürekkep } \\
\text { püskürtmeli }\end{array}$ & $\begin{array}{l}\text { Damlacik } \\
\text { birakma }\end{array}$ & $\begin{array}{l}\text { Faz değişimi yok; } \\
\text { materyalin reolojik } \\
\text { özellikleriyle kontrol } \\
\text { edilen katmanlar }\end{array}$ & $\begin{array}{l}\text { Reçel, çikolata, şekerleme, jöle, } \\
\text { likit hamur, peynir, et macunu }\end{array}$ \\
\hline \multirow{3}{*}{ 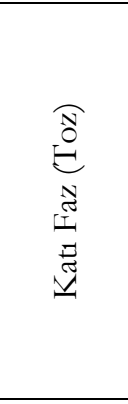 } & Sıv1 bağlayıcı & $\begin{array}{c}\text { Damlacık } \\
\text { birakma ve toz } \\
\text { bağlama }\end{array}$ & $\begin{array}{c}\text { Toz ile bağlayıcı } \\
\text { arasındaki adhesif } \\
\text { kuvvetler ve kimyasal } \\
\text { reaksiyonlar }\end{array}$ & $\begin{array}{l}\text { Çikolata, selüloz/ksantan } \\
\text { gam/glukomannan karışımı }\end{array}$ \\
\hline & $\begin{array}{l}\text { Selektif lazer } \\
\text { sinterleme }\end{array}$ & $\begin{array}{l}\text { Toz bağlama ve } \\
\text { 1s1 kaynağ1 } \\
\text { (lazer) }\end{array}$ & Sinterleme ve eritme & Şeker ve Nesquik \\
\hline & $\begin{array}{c}\text { Sicak hava } \\
\text { sinterleme ve } \\
\text { eritme }\end{array}$ & $\begin{array}{c}\text { Toz bağlama ve } \\
\text { 1s1 kaynağ1 } \\
\text { (s1cak hava) }\end{array}$ & Sinterleme ve eritme & Şeker \\
\hline 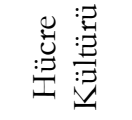 & Biyo-yazdirma & $\begin{array}{l}\text { Damlacik } \\
\text { birakma }\end{array}$ & $\begin{array}{l}\text { Kendiliğinden } \\
\text { yapılanan katmanlar }\end{array}$ & Et \\
\hline
\end{tabular}


Gida tasarımında 3D bask1 tekniğinin kullanılmasına yönelik araştırmalar hızla devam ederken, amaca uygun teknolojinin kullanıldığ 1 ticari 3D yazıcılar da pazarda yerini almaktadır. Günümüzde ticari olarak kullanılan farklı baskı teknolojileri ile çalışan 3D yazıcılara ait örnekler
Çizelge 2' de verilmiştir. Güncel literatür verileri ve gıdalar için uygun 3D bask1 teknolojilerinin avantajları ve dezavantajları göz önünde bulundurulduğunda en yaygın kullanılan gida bask1 teknolojisinin ekstrüzyon temelli bask1 teknolojisi olduğu görülmektedir.

Çizelge 2. Piyasadaki bazı 3D gida yazıcılarının avantaj ve dezavantajları (Sun vd., 2015c; Sun vd., 2018; Tan vd., 2018; Desktop Machinery, 2020; FoodBot, 2020)

\begin{tabular}{|c|c|c|}
\hline G1da Yazıcı Markası & Avantaj & Dezavantaj \\
\hline $\begin{array}{l}\text { Choc Creator V2.0 } \\
\text { Plus }\end{array}$ & Kablosuz ağa bağlanarak çalışabilme & Yalnızca çikolata baskısı \\
\hline Food Jetting Printer & Yüksek baskı kalitesi, kompleks tasarım & $\begin{array}{l}\text { Pahalı bask1 platformu, yüksek } \\
\text { enerji tüketimi }\end{array}$ \\
\hline Foodini & Sicakl1k kontrolü & $\begin{array}{l}\text { Bask1 materyali değiştirirken } \\
\text { zaman kayb1 }\end{array}$ \\
\hline Foodjet & Yüksek bask1 kalitesi & $\begin{array}{l}\text { Pahalı yazıc1 başlı̆̆1 ve baskı } \\
\text { platformu, yavaș bask1 }\end{array}$ \\
\hline BeeHex & Kendini temizleyebilme özelliği & $\begin{array}{l}\text { Temizleme } \\
\text { karmaşıklığ1 }\end{array}$ \\
\hline Barilla Pasta & İngrediyenlerin kolay hazırlanabilirliği & Yalnızca makarna baskısı \\
\hline Procusini 3.0 Dual & $\begin{array}{l}\text { Kolay kartuş dolumu ve manyetik kartuş } \\
\text { haznesi }\end{array}$ & Düşük üretim kapasitesi \\
\hline Ultimaker $2+$ & Çift başlık kullanılabilirliği & $\begin{array}{l}\text { Bask1 materyal haznesi 3D } \\
\text { yazıc1 sisteminin dişında }\end{array}$ \\
\hline F3D & Pişirme lambası & $\begin{array}{l}\text { Baskı işlemi ile eş zamanlı } \\
\text { pişirememe }\end{array}$ \\
\hline Chefjet & $\begin{array}{l}\text { Kompleks tasarım, renkli ürünler, kaliteli } \\
\text { bask1 oluşturulabilmesi }\end{array}$ & $\begin{array}{l}\text { Yavaş bask1, pahalı baskı } \\
\text { platformu }\end{array}$ \\
\hline Fab@Home & Modüler & $\begin{array}{l}\text { Açı kaynak kodlu olması; } \\
\text { internet saldırılarına } \\
\text { korumasız }\end{array}$ \\
\hline F5 & Yüksek kartuş kapasitesi & Yalnızca bir malzeme baskısı \\
\hline QiaoKe & Sürekli çalışabilme & Yalnızca çikolata baskısı \\
\hline Discov3ry 2.0 & Çift başlık kullanılabilirliği & $\begin{array}{l}\text { Bask1 materyal haznesi 3D } \\
\text { yazıc1 sisteminin dişında }\end{array}$ \\
\hline WiiBoox Sweetin & Kullanım kolaylığı & Düşük üretim kapasitesi \\
\hline Zmorph VX & Baskı hassasiyeti yüksek & Isıtma özellĭgi yok \\
\hline FoodBot D2 & $\begin{array}{l}\text { Çift başlık kullanılabilirliği, } \\
\text { hafızasında hazır tarifler bulunması }\end{array}$ & $\begin{array}{l}\text { Diğer yazıcılara göre yüksek } \\
\text { fiyat }\end{array}$ \\
\hline
\end{tabular}

Gidaların 3D baskisinda kullanilan hammaddeler farklı özellikte olabilir. Pasta sosu, peynir, çikolata, humus gibi hidrojel formunda olabilen baz1 malzemeler 3D baskı işleminin ardından yapısını ve şeklini kolaylıkla kararlı bir şekilde koruyabilir. $\mathrm{Bu}$ tür bask1 materyallerine yazdırılabilir (doğal) gıda maddeleri adı verilir ve baskı işleminin ardından elde edilen ürünlerde herhangi bir ileri 
işlemeye ihtiyaç duyulmaz. İnsanlar tarafindan yaygın olarak tüketilen bazı gıdalar (etler, pirinç, meyve, sebze v.b.) ise yazdırllamaz (geleneksel) gida maddeleri sınıflandırmasında yer almaktadır. Ön işlemler (meyvelerin/sebzelerin suyunu sıkma, pirinci haşlama veya öğütme, eti püre haline getirme vb.) uygulanarak ve formülasyon içerisine jelatin, K-karragenan, nişasta gibi hidrokolloidlerin ilavesi yapilarak doğrudan yazdirlamayan bu gidalara ekstrüzyon yeteneği kazandırilmaktadır (Southerland vd., 2011; Sun vd., 2015a; Bulut, 2019). Uygun gida bask1 materyallerinin seçimi ve formülasyonların hazırlanmasının ardından 3D baskı işlemi için hazırlanan gıda kartuşları yazıcıya yerleştirilmekte ve baskı işlemi başlamaktadır.

Kartuş içerisinde yer alan gidanın reolojik ve tekstürel özellikleri ile baskı işleminin ardından gıdanın şeklinin bozulmadan kalmasının sağlanabilmesi yüksek kaliteli 3D baskı işleminin başarısı için önemli hususlardır. Ayrıca, yazdırlacak ürünün şeklinin tasarımı, yazıcı yollarının baskı malzemesi ile olan uyumu, ekstrüzyon kanalının genişliği, şeklin katman yüksekliği, yazıcı başlı̆̆ının hareket hızı, nozul çap1, yazdırma yüksekliği gibi parametreler de 3D g1da bask1 kalitesini etkileyen önemli faktörlerdendir (Dankar vd., 2018; Bulut, 2019). Tüm bu faktörlerin optimize edilmesi ve başarllı bir 3D yazdırılmış ürün elde edebilmek için, konu üzerinde çalışan araştırmacıların gıdaların, kullanılan ingrediyenlerin özellikleri ve bileşimleri ile 3D yazıcı yazılım ve donanım özellikleri hakkında bilgi sahibi olmaları büyük önem taşımaktadır. Şekil 2'de 3D gida baskısında önem taşıyan bazı fizikokimyasal, reolojik ve yapısal parametreler verilmiştir.

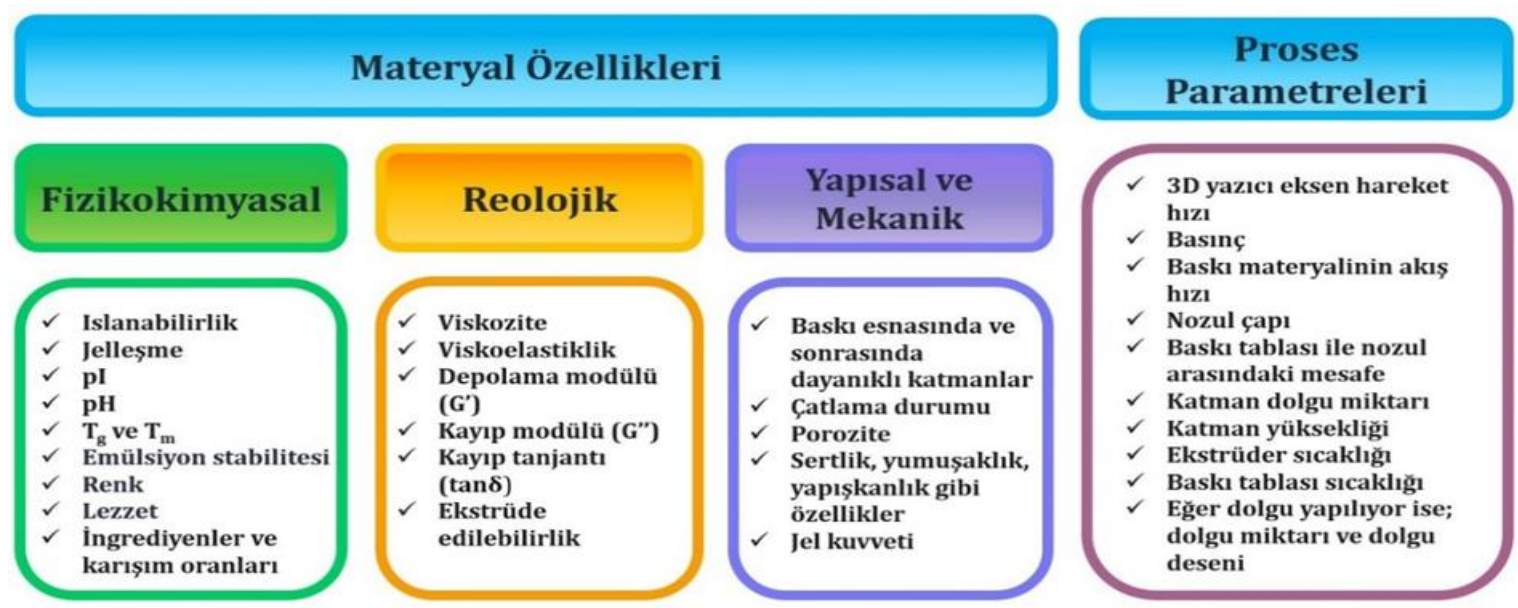

Şekil 2. 3D g1da baskısında önemli bazı faktörler (Dankar vd., 2018; Vancauwenberghe vd., 2018; Huang vd., 2019; Liu vd., 2019a; ArtıBoyut, 2020)

\section{D GIDA YAZICILARININ POTANSIYYEL KULLANIM ALANLARI}

Geleneksel gida üretim yöntemleri ile kıyaslandığında daha albenili ürünlerin, istenilen yap1 ve şekil kazandırılarak elde edilebilmesi, 3D bask1 teknolojisini heyecan verici bir alternatif haline getirmiştir. 3D gida baskısı, son y1llarda gündeme gelen; yaşlılar, çocuklar, hamileler ve sporcular gibi özel tüketici gruplarının taleplerini karşılamada önem taşıyan bir uygulamadır (Godoi vd., 2016; Aday ve Aday, 2020). Bu teknoloji ile çocuklar meyve-sebze tüketimi için teşvik edilmekte, yutma güçlüğü çeken bireyler için yumuşak tekstüre sahip ve kolay yutulabilir gıdalar üretilmekte, uygun tekstüre sahip yeni ürünler geliştirilmekte ve atık oluşumu azaltılabilmektedir (Yang vd., 2015; Kouzani vd., 2017).

Hobi, araştırma ve eğitim amaçlı kullanılabilen 3D gida yazıcıları gelecekte restoranlar gibi toplu tüketim yerlerinde, butiklerde özel tasarım gıdaların (şekerleme/kek/çikolata vb.) oluşturulmasında ve endüstride üretim amaciyla da aktif olarak kullanılabilecektir (Rubio ve Hurtado, 
2019). Ayrica, bu yazıcılar g1da üretiminde pilot testlerin yapilmasinda kullanilarak gida ve su israfinın azaltılmasina, enerjiden ve zamandan tasarruf sağlanmasına, böylece sürdürülebilir kalkınmaya katkı sağlayacaktır (Çelik, 2015; Yang vd., 2015). Yaşam döngü analizi ile makarna üretim ve dağıtım zincirinde 3D bask1 teknolojisinin sürdürülebilirliği ve çevreye etkisinin değerlendirildiği bir çalışmada (Lopez Galdeano, 2015), geleneksel üretim yöntemleri ile ekstrüzyon temelli 3D bask1 teknolojisi karşılaştırılmıştır. Makarna yazdırmak için gerekli olan aparatların makarna endüstrisi ekipmanları ile uygunluğu, üretimde kalıp kullanılmaması ve daha az işlem gerektirmesi 3D baskı teknolojisinin sürdürülebilir olduğunu göstermiştir. Sadece Avrupa'da ylda yaklaşık 77 milyon ton gida kaynaklı üretime ait ve evsel atık olduğu düşünülürse, 3D baskı teknolojisinin yaygınlaşmasıyla gıda israfinın yıllık 19 milyon ton azaltılacağ1, ayrıca, su ve enerji tasarrufu sağlanacağ1 sonucuna varılmıştır. Hollanda'daki Upprinting Food firmas1 bayat ekmek, zedelenmiş satılamayan meyve ve sebzeler, restoranlardaki artan gidaları kullanarak 3D yazdırılmış atıştırmalık ürünler üreterek yiyeceklerin israf edilmeden geri dönüştürülebileceğini göstermiştir (Boissonneault, 2019).

Meslekleri gereği belirli zamanlarda izole edilmiş bölgelerde çalışma yapmak zorunda olan jeoloji, çevre bilimi ve uzay bilimi ile ilgilenen uzmanlar 3D yazıcıları kullanarak kendi gidalarını üretebilirler (Boissonneault, 2019). NASA, 2013 yılında 3D yazıcılar ile uzay istasyonlarında isteğe bağlı gıda üretimi için önemli bir proje bütçesi ayırmış (Terfansky vd., 2013), böyle bir proje ile uzayda gıda depolama sorunun çözülmesi, astronotların dengeli bir şekilde kalori alımının sağlanması, profesyonel bir personele ihtiyaç duymadan 3D yazıcılar ile çok çeşitli ve istenilen özellikte gidaların üretiminin sağlanması amaçlanmıştur (Lin, 2015; NASA, 2015). Bu teknoloji ile uzayda nispeten daha basit bir pişirme ve gıdaların yazdırlarak taze bir şekilde tüketilmesi planlanmıştır (Lin, 2015).

Disfaji (yutma ve çiğneme güçlüğü); Alzheimer, Parkinson, beyin felci, Amyotrofik Lateral Skleroz (ALS) gibi hastalıkların sonucu olarak ortaya çıkan, bireylerin yaşam kalitesini etkileyen önemli bir sorundur (Ortega vd., 2017; Seo vd., 2019). Disfajiden muzdarip bireyler uygun k1vama sahip gidalar tüketmelidirler. Aksi takdirde boğulma, nefes alamama, aspirasyon pnömonisi gibi sorunlar ortaya çıkabilmektedir (Kouzani vd., 2017). Ayrıca, özellikle yutma güçlüğü çeken yatan hastaların günlük diyetlerindeki protein ve kalori hedeflerine mümkün olan en kısa sürede ulaşılması gerekmektedir (Arsava vd., 2018). Et ve et ürünleri bu hastaların protein ihtiyacinın karşılanması için en önemli kaynaklardandır. Et doğası gereği sert bir yapiya sahip olmasina rağmen 3D baskısı için formülasyon bileşiminde yapısı modifiye edilebilmekte ve yutma güçlüğü çeken bireylerin tüketebileceği form sağlanabilmektedir (Dick vd., 2019). Günümüzde disfajiden muzdarip bireyler için piyasada kıvamı arttırılmış içecekler, meyve ve sebze püreleri ile su katılarak yumuşatılmış gıdalar bulunmaktadır. Fakat, bu gıdaların görünüş, tekstür ve lezzet özellikleri bu bireylerde g1da tüketimi konusunda isteksizliğe neden olmaktadır. 3D baskı teknolojisi ile disfaji sorunu yaşayan kişiler için daha yumuşak tekstürlü, bireylerin ihtiyaç duyduğu besin içeriklerine sahip, görsel çekiciliği arttırılmıs, sürdürülebilir gıdalar hazırlanabilmektedir (SSekil 3). Böylece, bireylerin iştahsızlık sorunu azalılıp, gıdaları zevkle tüketmeleri de sağlanacağından yaşam kalitesi arttırlabilmektedir (Kouzani vd., 2017). 3D yazıcılar bu amaçla yaşlı ve/veya özel tedavi gören hastaların bulunduğu bakım evlerinde rahatlikla tercih edilebilecektir.

Çocuklar genellikle, meyve ve sebze yeme açısından çok istekli olmayıp, bu gıdaların şekil, tat, renk, koku ve tekstür özellikleri konusunda oldukça seçicidirler. Halbuki, meyve ve sebzeler vitamin, mineral, antioksidan, lif ve diğer gerekli besin ögelerini içerdikleri için çocukların gelişimi için oldukça değerli gıdalardır. 3D baskı teknolojisi, meyve ve sebzelere ek olarak, bu gıdalarda bulunmayan vücuda faydalı bileşenleri katmanlar arasına sıkıştırarak meyve ve sebze alımını sağlayacak albenili, yeni bir tekstüre sahip, eğlenceli ve/veya besleyici gidalar üretebilen, çocuk dostu şekiller oluşturma yeteneğine sahip bir teknolojidir (Azam vd., 2018). Kelebek şeklindeki kurabiye üzerine yapılan süslemeler, 
ekmek üzerine kuş şeklinde yapılmış çilek reçeli baskıs1, kelebek şeklinde yazdırılmış buğday unu ve kültür mantarı içeren atıştırmalıklar, D vitamini ile zenginleştirilmiş ve çeşitli şekillerde yazdırılmış portakal suyu konsantresi gibi gidalar bu teknoloji ile yazdırilabilmektedir (Azam vd., 2018; Sun vd., 2018; Zhao vd., 2018; Keerthana vd., 2020). Derossi vd. (2017) tarafindan gerçekleştirilen bir çalı̧şada, beyaz fasulye, kurutulmuş mantar, yağsız süt tozu, askorbik asit, limon suyu, muz ve pektin solüsyonu kullanılarak hazırlanmıs bir formülasyonun 3D baskısı gerçekleştirilerek çocuklar için demir, kalsiyum ve D vitamini yönünden zengin atıştrrmalık ürünler oluşturulmuştur. Bu teknoloji, et tüketicilerine (özellikle yaşlılar ve çocuklara) yönelik geliştirilmiş dokusu ile içeriği ayarlanarak yüksek kaliteli, fonksiyonel et tabanlı ürünler elde etmede yeni ve heyecan verici bir alternatif sağlamaktadır (Bulut vd., 2019a; Bulut vd., 2019b).
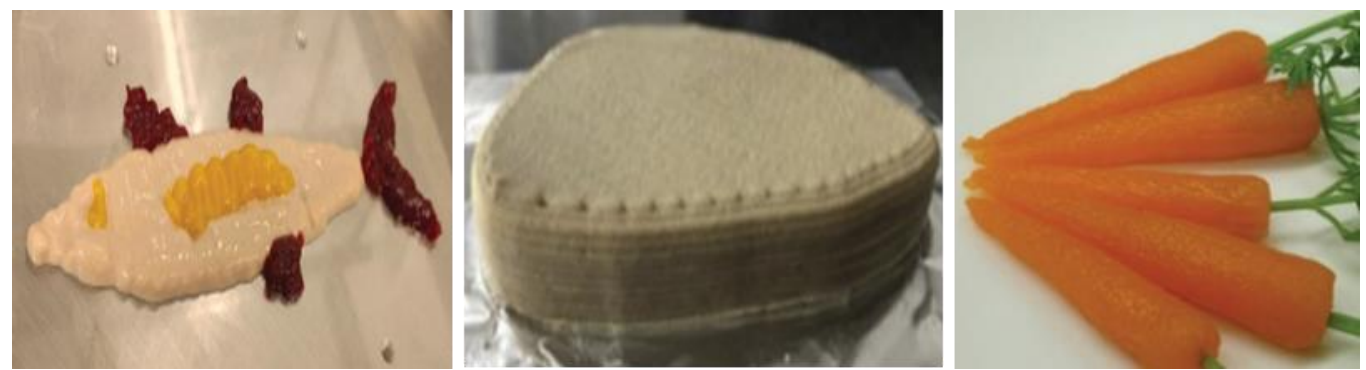

Şekil 3. Tekstürü modifiye edilmiş balık eti, domuz eti, havuç püresi örnekleri (Kouzani vd., 2017; Noort vd., 2017; Dick vd., 2020)

Günümüzde vücut direncini artırmak, saç ve deri onarımına yardımcı olmak, bağışıklık sistemini güçlendirmek, zihin gelişimini desteklemek gibi fonksiyonel işlevlere sahip farklı gida bileşenleri kullanılarak kişiye özel gidalar ticari olarak da üretilmeye başlanmıştır. İngiltere'de bulunan Nourished firması tarafindan kişinin ihtiyaçları doğrultusunda pek çok alternatif gida içerisinden seçilen maça turpu (Lepidium meyenii) tozu, $\mathrm{B}_{12}$ ve C vitaminleri, beta glukan, likopen, demir ve karabiber ekstraktı gibi bileşenler ile üretilen 3D yazdırılmış fonksiyonel ürünler Şekil 4(a)'da gösterilmiştir (Nourished, 2019). Benzer şekilde alerjik bünyeye sahip olan kişilerin ihtiyacına uygun olarak özel gıdalar da üretilebilmektedir. Barilla'nın da desteğiyle BluRhapsody firması tarafından ticari olarak üretilen estetik şekilli makarnalar (Şekil 4 (b)) internet sitesi üzerinden satışa sunulmuştur (Wolf, 2019).

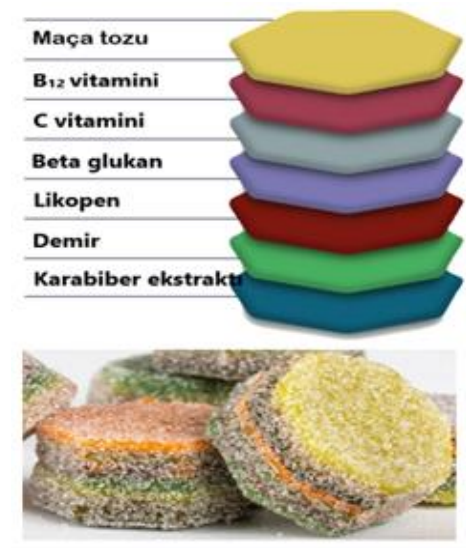

(a)

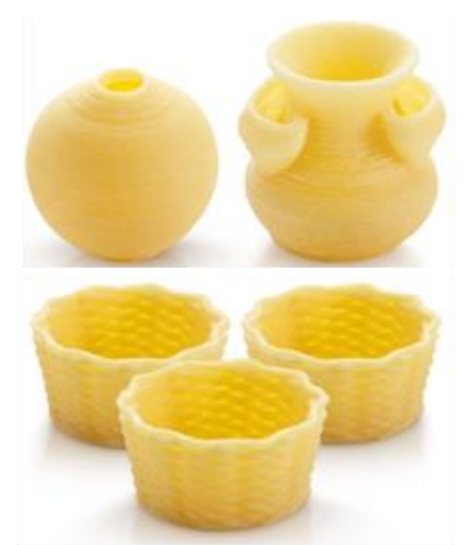

(b)

Şekil 4. (a) Özel ihtiyaçlar için hazırlanmış, 3D yazdırılmış fonksiyonel gıda örneği (Nourished, 2019), (b) BluRhapsody firması tarafindan üretilen makarnalar (BluRhapsody, 2019) 
3D yazıcılarla şeker, hamur, çikolata, peynir vb. çeşitli gidalar ile hem lezzetli hem de görsel olarak çekici şekerlemeler veya yiyecek süslemeleri yazdirllabilmektedir. Bu sistemler kullanılarak birbirine geçen tatllar, çeşitli şeker heykelleri ve bütün haldeki dügün pastaları gibi karmaşık yapılar oluşturulabilmektedir (Liu vd., 2017). Şekil 5’te 3D yazıcıda yazdırılmıs çikolata, reçel, portakal suyu konsantresi ve makarna örnekleri verilmiştir (Noort vd., 2017).
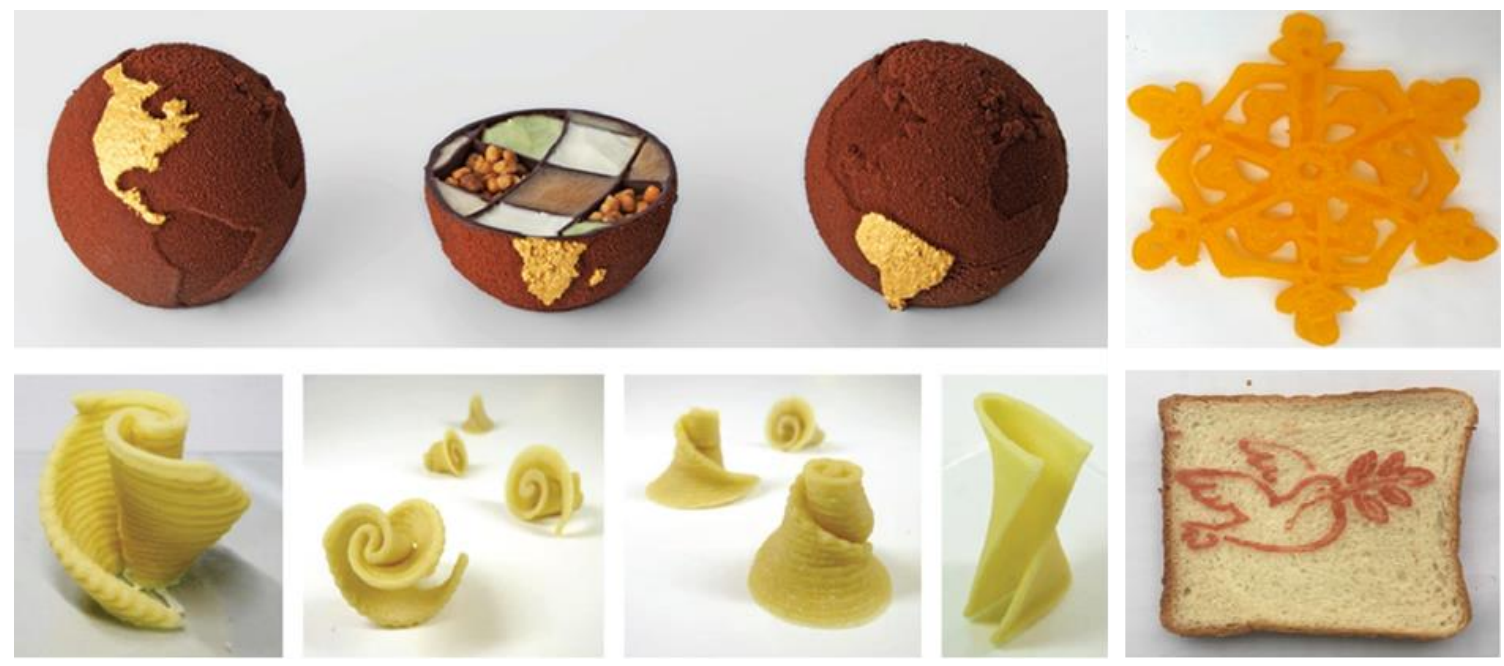

Şekil 5. 3D yazdırılmış albenili ürünler (Noort vd., 2017; Azam vd., 2018; Zhao vd., 2018)

\section{GELECEKTE 3D GIDA YAZICILARI}

Profesyonel 3D yazıcilar, yeni gida malzemeleri, tasarım ve 3D baskı süreçleri arasındaki entegrasyonla birlikte, 3D gıda baskı çalışmalarına olan eğilimin önümüzdeki yllarda artarak devam etmesi beklenmektedir. FAO'nun yayınladığ1 verilere göre dünya nüfusunun 2050 yllına kadar 9.1 milyara ulaşacağ1 öngörülmektedir (FAO, 2019). Artan dünya nüfusu, iklim değişikliği, su k1tlyğ1 ve g1da israfi gibi konular gida güvencesi için ciddi bir tehdit oluşturmakta, gelecekte dünya nüfusunun nasıl besleneceği ile ilgili kaygılar da günden güne artmaktadır. 3D g1da bask1 teknolojisi bu riskleri ve kayglları azaltmada önemli bir rol oynama potansiyeline sahiptir.

İmalat sanayiini inşa ederken fiziksel altyap1, makine ve teçhizat masrafları, personel ihtiyaçları vb. giderleri karşılamaya ihtiyaç vardır. Bu masraflar gelişmekte olan ülkelerde imalat yapmak için çoğu zaman bir engel teşkil etmektedir. 3D bask1, sürdürülebilir kalkınma için alternatif bir yol sunabilir ve gelişmekte olan ülkelerin önemli fiziksel altyapı yatırımlarına ihtiyaç duymadan endüstriyel rekabet güçlerini geliştirmelerine yardımc1 olabilir. 3D bask1 teknolojisi, zaman içerisinde bireysel serbest çalışanlara ve küçük ölçekli üreticilere de iş fırsatları sunacaktır (Fuldaer, 2019).

Hücre kültürü teknolojisi 3D baskı teknolojisine entegre edilerek lezzeti ve tekstürü hayvan etine benzeyen et ve et ürünleri oluşturulabilmektedir. Bu sayede, 3D g1da bask1 teknolojisinin hayvan refahı korunarak, su israfi ve çevreye karbon salınımı olmadan dünya gıda krizinin çözümüne yardımcı olacağı, böylece çevreye verilen zarann azaltılacağ1 tahmin edilmektedir (Atlantic Council, 2011). Fonksiyonel gidalar kapsamında 3D baskı teknolojisi ile yağ, tuz ve şeker içeriği azaltulmış ürünler üretilerek bireylerin yaşam kalitesi iyileştirilebilir. Gıdalann kişiselleştirilmesinin yanı sıra, yazıcının ilgili ayarları yapılarak bireyler için oluşturulacak gidalarda porsiyon kontrolünün de sağlanabileceği düşünülmektedir (Rubio ve Hurtado, 2019; Caulier vd., 2020).

Otomat makineleri şeklinde olabilen 3D gida yazıcıları okullar, kütüphaneler, huzurevleri, hastaneler, tren istasyonları, alısveriş merkezleri vb. yerlerde taze hazırlanmış, kişiselleştirilmiş gıdaların oluşturulabilmesine olanak sağlayacaktır. 
Yakın gelecekte 3D yazıcılara internet üzerinden bağlı herhangi bir cihaz kullanılarak doğrudan kullanıcı hesabından sipariş vermek de mümkün olacaktır (Rubio ve Hurtado, 2019).

3D g1da baskıs1, teknolojisinin sunduğu birçok avantaja rağmen hem teknolojik hem de sosyal açıdan zorluklarla karşı karşıyadır. Teknolojik açıdan değerlendirildiğinde, gida endüstrisinin dikkatini çeken, hızla gelişen bu teknolojinin endüstriye entegre edilebilir şekilde ölçeklendirilmesine ihtiyaç vardır. Ayrıca, 3D yazdırılan gıda formülasyonuna bağlı olarak, yazıcı besleme sistemlerinin ve baskı için sıcaklık sistemlerinin kontrollerinin yapılmas1, bask1 platformunun ve yazıcı başlıklarının baskıya uygun şekilde ayarlanması gerekmektedir. Bunların yanı sıra, gıda baskısı gerçekleștirilirken mikrobiyel stabilitenin ve gıda güvenliğinin sağlanması da ele alınması gereken bir diğer konudur. Beslenme kalitesini, lezzetini ve güvenliğini iyileştirmek için gıdaların çoğunun baskı sonrası ayrı bir işlemden geçirilmesi gerekecektir. Sosyal açıdan bakıldığında ise tüm yeni teknolojilerde olduğu gibi, imalat işlerini azaltacak, bu dezavantaj özellikle, insan iş gücü maliyetinin düşük olduğu ülkelerin ekonomilerinde olumsuz bir etki yapacaktır (Akben, 2017). Sosyal açıdan bir diğer dezavantaj da tüketicilerin "3D bask1" terimine olan yaklaşımlanıdır. Lupton ve Turner (2017) tarafından yürütülen bir çalışmada, 3D yazdırılmış çeşitli gıdaların 30 panelist tarafindan değerlendirilmesi istenmiş, tüketicilerin yazdırılan gıdalara karşı olan tutumları incelenmiştir. Bazı katılımcılar 3D yazdırılmış gıdaların bakteri yükünün çok yüksek olduğundan endişe duyarken, diğer bir grup katilımc1 3D gida baskisinda renkli mürekkepler, kimyasallar ve plastik gibi malzemelerin kullanıldığından endişe duyduklarını belirtmişlerdir. Manstan ve McSweeney (2020) tarafindan gerçekleştirilen bir çalışmada, 3D yazdırilmış kurabiye, pizza, köfte ve patates püresi ürünlerinin 329 tüketici tarafindan kabul edilebilirliği test edilmiştir. İlk olarak tüketicilerin 3D g1da baskısı teknolojisi ve 3D yazdırlan ürünler karşısındaki tutumlarını belirlemek için anket yapılmış, bu anketten elde edilen yanıtlara göre üç grup belirlenmiştir. Birinci grupta, 3D gida baskısı hakkında daha fazla bilgi edinmek isteyen ve bu teknolojinin ürün maliyetini düşürebileceğine ve yararlan arttırabileceğine inanan 140 katılımc1; ikinci grupta, 3D yazdırılmış gidalar1 denemekten heyecan duymayan 98 katılımc1; üçüncü grupta ise, 3D yazdırılan ürünlerin kabul edilemez olduğuna ve bu gidaların tüketmek için güvenilir olmadığına inanan 91 katılımc1 yer almıştır. Mantihal vd. (2019) tarafindan gerçekleştirilen bir çalışmada, tekstürü modifiye edilerek 3D yazdırılmış çikolatanın tercih durumu ve tüketici alg1sı üzerine iki test gerçekleştirilmiştir. Illk testte, otuz yanı eğitimli panelistten sirasiyla $\% 25, \% 50$ ve $\% 100$ dolgu yüzdesine sahip bal peteği desenli olarak 3D yazdırılmış üç adet çikolata örneğinde görünüş ve sertlik özelliklerine bağlı tercihlerini belirtmeleri; ikinci testte ise aynı panelistlere \%100 dolgu yüzdesine sahip 3D yazdırılmış ürün ile ticari çikolata örneği arasındaki tercihlerini ifade etmeleri istenmiştir. Sertlik için genel tercihlerde önemli bir fark olmadığ1; ancak panelistlerin, $\% 100$ dolguya kiyasla $\% 25$ ve $\% 50$ dolgu yüzdesine sahip örneklerin görünüşünü daha çok tercih ettikleri görülmüştür. Ayrıca, ticari ve $\% 100$ dolgu örnekleri arasında tercih açısından önemli bir fark belirlenmemiştir.

Son ylllarda oldukça yoğun bir şekilde araştırilan 3D bask1 teknolojisinin her yeni teknolojide olduğu gibi geliştirilmeye ihtiyacı vardır. 3D bask1 teknolojisinin eksik yönlerini tamamlamak amacıyla geliştirilen 4D bask1, ilk kez 2013 yılında ortaya atılmış yeni bir teknolojidir (Miao vd., 2017). 4D bask1 teknolojisi, 3D baskının devam1 niteliğinde bir teknoloji olup 3D baskıya çok benzer bir teknoloji kullanılmaktadır. Ancak nem, $\mathrm{pH}$, sıcaklık gibi parametreler değiştirilerek yazdırılan materyallerin şekli, duyusal özellikleri (renk, tat ve lezzet) ve işlevselliği istenildiği gibi değiştirilebilmektedir (Şekil 6). Bu değişim dördüncü boyut olarak nitelendirilmektedir (Javaid ve Haleem, 2019).

4D yazdırılan gıdaların özelliklerinin zaman içerisinde değişebilir olması özellikle iştahsız çocukların yemek deneyimlerini daha eğlenceli bir hale getirebilir. 4D kavramının temelleri giderek daha net hale geldikçe tıp, kimya, malzeme bilimi ve gida gibi birçok alanda uygulaması artacaktır 
(Truby ve Lewis, 2016; Miao vd., 2017). Kompozit malzemelerde 4D baskının kullanıldığ1 güncel çalışmalar bulunmaktadır (Hoa ve Cai, 2020; Oladapo vd., 2020; Shao vd., 2020). Bu teknoloji mühendislerin, tasarımciların hayal gücünü harekete geçirerek yeni ürünlerin geliştirilmesi ve yeni fikirlerin uygulanması için yardımcı olacaktır.

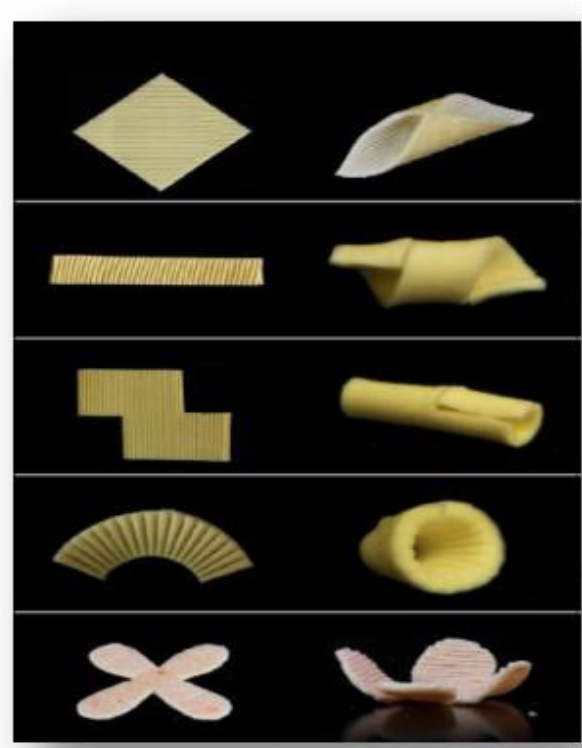

(a)

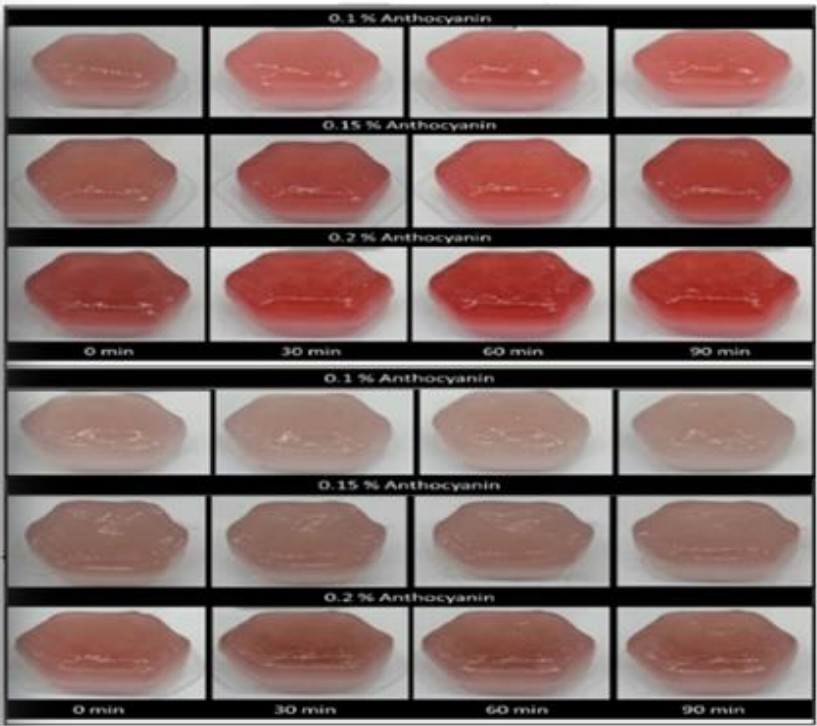

(b)

Şekil 6. 4D teknoloji kullanılarak oluşturulan örneklerde (a) sicaklık etkisiyle şekilde, (b) süre ve antosiyanin konsantrasyonu etkisiyle renkte meydana gelen değişim (Ghazel vd., 2019; Tao vd., 2019)

\section{SONUÇ}

Yapılan araştırmalar doğrultusunda 3D gida yazıcıları ile gerçekleştirilen çalışmaların hızla devam ettiği ve gelecekteki kullanım potansiyelinin oldukça yüksek olduğu görülmektedir. 3D gıda bask1 teknolojisi, kişiye özel gidaların üretimi, gidaların raf ömrünü uzatma, yeni tekstür ve içeriğe sahip fonksiyonel ürünlerin üretimi gibi avantajlarından ötürü gida teknolojisinde yeni ve ilgi çekici bir alternatif sağlamaktadır. Ham madde kayıplarının azaltılması ve atıkların fonksiyonel gıdaların üretimine dahil edilebilir olması, karbon ayak izini azaltması, prototip üretilirken kişi veya işletmelere zaman ve maliyet tasarrufu sağlanması gibi avantajları sebebiyle gelecek yıllarda gida endüstrisinin daha çok ilgisini çekeceği ön görülmektedir. En yeni teknolojilerle birlikte 3D gıda yazıcılarının gelişmesi, yazdırılabilir gıda formülasyonlarının iyileştirilmesi, 4D baskı teknolojisinin ilerlemesi ve yazdırlacak ürün tasarımlarının çeşitlendirilmesi ile 3D gıda yazıcılarının kullanımında bir artış gözleneceği aşikârdır. İnsanların yaşam kalitesini artırmak ve sürdürülebilir kalkınmayı hızlandırmak için toplumların teknolojiyi kullanarak iş birliği içinde olmasının sağlanması amacıyla ortaya çıkan Toplum 5.0 kavramı içerisinde 3D g1da yazıcılarının gelecekte daha çok yer alacağı düşünülmektedir.

\section{ÇIKAR ÇATIŞMASI BEYANI}

Yazarların, başka kişiler ve/veya kurumlar ile çıkar çatışması bulunmamaktadır.

\section{YAZAR KATKILARI}

KC ve EGB makaleyi birlikte planlamıs, yazım, inceleme ve düzenleme aşamalarında katkıda bulunarak, son halini okumuş ve onaylamışlardır.

\section{TEŞEKKÜR}

$\mathrm{Bu}$ çalışma, Türkiye Bilimsel ve Teknolojik Araşturma Kurumu (TÜBİTAK) tarafindan desteklenmiştir (Proje No: 218 O 017). 


\section{KAYNAKLAR}

Aday,S., Aday, M.S. (2020). 3 Boyutlu yazıciların gıda endüstrisinde kullanımı. Türkiye 13. Gıda Kongresi, 21-23 Ekim 2020, Çanakkale, Türkiye, $444 \mathrm{~s}$.

Akben, İ. (2017). 3 Boyutlu yazıcılar ve tedarik zincirine etkileri. JAVStudies, 3(10): 20-35, doi: 10.23929/javs.170.

Arlı, B., Demirbaş, Y.K. (2015). Uygulamalarla 3 Boyutlu Yazrc Yapımı ve Kullanmm. Abaküs Kitap Yayınevi, Fatih, İstanbul, 272 s. ISBN-13 :9786059129022.

Arsava, E.M., Aydoğdu, İ., Güngör, L., Togay Işıkay, C., Yaka, E. (2018). İnme hastalarında nütrisyonel yaklaşım ve tedavi, Türkiye için uzman görüşü. Türk Nöroloji Dergisi, 24: 226-242. doi: $10.4274 /$ tnd.92603.

ArtıBoyut (2020). 3D Yazıc1-Basım yapilırken dikkat edilmesi gerekenler. https://www.artiboyut.com./index.php/tr/bilgibankasi/48-3d-\%20yazici-basimyapilirken dikkatedilmesi-gerekenler (Erişim Tarihi: 09 Eylül 2020).

Atlantic Council (2011). Strategic foresight report-Could 3D printing change the World? Technologies, potential, and implications of additive manufacturing. Washington DC, the USA.

Azam, R.S.M., Zhang, M., Bhandari, B., Yang, C. (2018). Effect of different gums on features of 3D printed object based on vitamin-d enriched orange concentrate. Food Biophys., 13(3): 250-262. doi: 10.1007/s11483-018-9531-x.

Bakan, İ., Erşahan, B., Kefe, İ., Bayat, M. (2011). Kamu ve özel hastanelerde tedavi gören hastaların sağlıkta hizmet kalitesine ilişkin algılamaları. KSÜ İ̈BF Dergisi, 1(2): 1-16.

Berman, B., Zarb, F.G., Hall, W. (2012). 3-D printing: the new industrial revolution. Bus Horiz, 55(2): 155-162. doi: 10.1016/j.bushor. 2011.11.003.

BluRhapsody. (2019). Shop. https://blurhapsody.com/shop-pasta-3d/ (Accessed: 28 October 2020).
Boissonneault, T. (2019). Upprinting food transforms food waste into edible 3D printed snacks. https://www.3dprintingmedia.network/ upprinting-food-food-waste-edible-3d-printedsnacks/ (Accessed: 01 October 2020).

Bulut, E.G. (2019). Üç Boyutlu (3D) Gıda Yazıcısı Kullanilarak Fonksiyonel Tavuk Eti Ürünü Üretimi. Ankara Üniversitesi Fen Bilimleri Enstitüsü Gıda Mühendisliği Anabilim Dalı Yüksek Lisans Tezi, Ankara, Türkiye, 94 s.

Bulut, E.G., van Bommel, K., Candoğan, K. (2019a). 3B yazıcı kullanılarak fonksiyonel tavuk eti ürünü üretimi. 5. Uluslararası Beyaz Et Kongresi, 24-28 Nisan, Manavgat, Türkiye, 95-99 s.

Bulut, E.G., van Bommel, K., Candoğan, K. (2019b). Development of a fuctional chicken meat-based snack by 3D food printing: effects of starch addition and cooking methods. XVIII European Symposium on the Quality of Eggs and Egg Products and XXIV European Symposium on the Quality of Poultry Meat, 23-26 June, Book of Abstracts, Çeşme, Turkey, 153 p.

Caulier, S., Doets, E., Noort, M. (2020). An exploratory consumer study of 3D printed food perception in a real-lifemilitary setting. Food Qual Pref., 86: 104001. doi:10.1016/j.foodqual. 2020.104001 .

Çelik, D. (2015). Üç Boyutlu Yazıcı Tasarımı, Prototipi ve Tersine Mühendislik Uygulamaları. Karabük Üniversitesi Fen Bilimleri Enstitüsü Endüstriyel Tasarım Mühendisliği Anabilim Dalı Yüksek Lisans Tezi, Karabük, Türkiye, 220 s.

Dankar, I., Haddarah, A., Omar, F.E.L., Sepulcre, F., Pujola, M. (2018). 3D printing technology: The new era for food customization and elaboration. Trends Food Sci Technol., 75: 231-242. doi: 10.1016/j.tifs.2018.03.018.

Derossi, A., Caporizzi, R., Azzollini, D., Severini, C. (2017). Application of 3D printing for customized food. A case on the development of a fruit-based snack for children. J. Food Eng., 5(2): 65-75. doi: 10.1016/j.jfoodeng.2017.05.015. 
Desktop Machinery (2020). Wiiboox Sweetin. https://www.desktopmachinery.com/product/ wiiboox-sweetin/ (Accessed: 10 Eylül 2020).

Dick, A., Bhandari, B., Prakash, S. (2019). 3D printing of meat. Meat Sci., 153: 35-44. doi: 10.1016/j.meatsci.2019.03.005.

Dick, A., Bhandari, B., Dong, X., Prakash, S. (2020). Feasibility study of hydrocolloid incorporated 3D printed pork as dysphagia food. Food Hydrocoll., 107: $105940 . \quad$ doi: 10.1016/j.foodhyd.2020.105940.

FAO (2009). How to Feed the World in 2050. http://www.fao.org/fileadmin/templates/wsfs/ docs/expert_paper/How_to_Feed_the_World_i n_2050.pdf (Accessed: 17 Eylül 2020).

Feng, P., Mneg, X., Chen, J.F., Ye, L. (2015). Mechanical properties of structures 3D printed with cementitious powders. Constr Build Mater., 93: 486-497.

10.1016/j.conbuildmat.2015.05.132.

FoodBot (2020). Foodbot D2 multi ingredient dual head food 3D printer. https://www.3dprintersonlinestore.com/foodbo t-d2-food-3d-printer (Accessed: 10 Eylül 2020).

Fuldauer, E. 2019. 3D printing will boost sustainable development. https://www.smartcitylab.com/blog/digitaltransformation/3d-printing-will-boostsustainable-development/ (Accessed: 11 Ekim 2020).

Ghazel, A.F., Zhang, M., Liu, Z. (2019). Spontaneous color change of 3D printed healthy food product over time after printing as a novel application for 4D food printing. Food Bioproc Tech., 12: 1627-1645. doi: 10.1007/s11947-01902327-6.

Godoi, F.C., Prakash, S., Bhandari, B.R. (2016). 3D printing technologies applied for food design: Status and prospects. J Food Eng., 179: 44-54. doi: 10.1016/j.jfoodeng.2016.01.025.

Godoi, F.C., Bhandari, B.R., Prakash, S., Zhang, M. (2019). An introduction to the principles of 3D food printing. In: Fundamentals of 3D Food Printing and Applications, Godoi, F.C. (ed.), Bhandari, B.R. (ed.), Prakash, S. (ed.), Zhang, M. (ed.), Academic Press, London, the UK, pp. 1-18. ISBN: 012814565X, 9780128145654.

Hoa, S.V., Cai, X. (2020). Twisted composite structures made by $4 \mathrm{D}$ printing method. Compos Struct, 238: $111883 . \quad$ doi: 10.1016/j.compstruct.2020.111883.

Holland, S., Tuck, C., Foster, T. (2018). Selective recrystallization of cellulose composite powders and microstructure creation through 3D binder jetting. Carbohydr Polym., 200: 229-238. doi: 10.1016/j.carbpol.2018.07.064.

Huang, M., Zhang, M., Bhandari, B. (2019). Fabrication of gel-like emulsions with whey protein isolate using microfluidization: Rheological properties and 3D printing performance. Food Bioproc Tech., 12: 1185-1196. doi: 10.1007/s11947-019-02344-5.

Hull, CW.1984. Apparatus for production of three-dimensional objects by stereolithography. Google Patents. US4575330A.

Izdebska, J., Zolek-Tryznowska, Z. (2016). 3D food printing - facts and future. Agro Food Industry Hi Tech., 27(2): 33-36.

Javaid, M., A. Haleem. (2019). 4D printing applications in medical field: A brief review. Clin Epidemiol Glob Health, 7(3): 317-321. doi: 10.1016/j.cegh.2018.09.007.

Keerthana, K., Anukiruthika, T., Moses, J.A., Anandharamakrishnan, C. (2020). Development of fiber-enriched 3D printed snacks from alternative foods: A study on button mushroom. J Food Eng., 287: 110116. doi: 10.1016/j.jfoodeng. 2020.110116.

Kouzani, A.Z., Adams, S.,J. Whyte, D., Oliver, R., Hemsley, B., Palmer, S., Balandin, S. (2017). 3D Printing of food for people with swallowing difficulties. The International Conference on Design and Technology, 05-08 December, Geelong, Australia, 23-29 p.

Lin, C. (2015). 3D food printing: A taste of the future. J Food Sci Educ., 14(3): 86-87. doi: 10.1111/1541-4329.12061.

Liu, Z., Zhang, M., Bhandari, B., Wang, Y. (2017). 3D printing: Printing precision and application in 
food sector. Trends Food Sci Technol., 69(A): 83-94. doi: 10.1016/j.tifs.2017.08.018.

Liu Z, Bhandari B, Prakash S, Zhang M. (2018). Creation of internal structure of mashed potato construct by 3D printing and its textural properties. Food Res Int., 111: 534-543. doi: 10.1016/j.foodres.2018.05.075.

Liu, Y., Yu, Y., Liu, C., Regenstein, J.M., Liu, X., Zhou, P. (2019a). Rheological and mechanical behavior of milk protein composite gel for extrusion-based 3D food printing. LWT-Food Sci Technol., 102: 338-346. doi: 10.1016/j.lwt. 2018.12.053.

Liu, Y., Zhang, W., Wang, K., Bao, Y., Renstein, J.M., Zhou, P. (2019b). Fabrication of gel-like emulsions with whey protein isolate using microfluidization: Rheological properties and 3D printing performance. Food Bioproc Tech., 12: 19671979. doi: 10.1007/s11947-019-02344-5.

Lopez Galdeano, J.A. (2015). 3D Printing Food: The Sustainable Future. Master Thesis, Kaunas University, Kaunas, Lithuania, 104 p.

Lupton, D., Turner, B. (2017). Both fascinating and disturbing: Consumer responses to 3D food printing and implications for food activism, In: Digital Food Activism, Schneider, T. (ed.), Eli, K.(ed.), Dolan, C.(ed.), Ulijaszek, S. (ed.), Taylor \& Francis Group, Routledge, the UK, pp. 150167. doi: 10.4324/9781315109930.

Manstan, T., McSweeney, M.B. (2020). Consumers' attitudes towards and acceptance of 3D printed foods in comparison with conventional food products. J. Food Sci Technol., 55: 323-331. doi: 10.1111/ijfs.14292.

Mantihal, S., Prakash, S., Bhandari, B. (2019). Texture-modified 3D printed dark chocolate: Sensory evaluation and consumer perception study. J. Texture Stud., 50: 386-399. doi: 10.1111/jtxs.12472.

Miao, S., Castro, N., Nowicki, M., Xia, L., Cui, H., Zhou, X., Zhu, W., Lee, SJ., Sarkar, K., Vozzi, G., Tabata, Y., Fisher, J., Zhang, L.G. (2017). 4D printing of polymeric materials for tissue and organ regeneration. Mater Today, 20(10): 577-591. doi: 10.1016/j.mattod.2017.06.005.
Nachal, N., Moses, J. A, Karthik, P., Anandharamakrishnan, C. (2019). Applications of 3D printing in food processing. Food Eng Rev., 11: 123-141. doi: 10.1007/s12393-019-09199-8.

NASA (2015). 3D food printer in space. https://open.nasa.gov/innovation-space/3d-

food-printer-in-space/ (Accessed: 30 Eylül 2020).

Noort, M. W. J., van Bommel, K., Renzetti, S. (2017). 3D-printed cereal foods. Cereal Foods World, 62(6): 272-277. doi: 10.1094/CFW-62-60272.

Nourished (2019). Nourished lab. https://getnourished.com/pages/lab (Accessed: 13 Haziran 2020).

Oladapo, B.I., Oshin, E.A., Olawumi, A.M. (2020). Nanostructural computation of 4D printing carboxymethylcellulose (CMC) composite. Nano-Struct. Nano-Objects, 21: 100423. doi: 10.1016/j.nanoso.2020.100423.

Ortega, O., Martin, A., Clave, P. (2017). Diagnosis and management of oropharyngeal dysphagia among older persons, state of the art. J Am Med Dir Assoc., 18(7): 576-582. doi: 10.1016/j.jamda.2017.02.015.

Ötleş, S. (2016). Gıda sektöründe üç boyutlu yazıcıların kullanım olanakları. Dünya Gida, 2016(11): 110-114.

Pallottino, F., Hakola, L., Costa, C., Antonucci, F., Figorilli, S., Seisto, A., Menesatti, P. (2016). Printing on food or food printing: A review. Food Bioproc Tech., 9(5): 725-733. doi: 10.1007/s11947016-1692-3.

Prakash, S., Bhandari, B.R., Godoi, F.C., Zhang, M. (2019). Future outlook of 3D food printing. In: Fundamentals of 3D Food Printing and Applications, Godoi, F.C. (ed.), Bhandari, B.R. (ed.), Prakash, S. (ed.), Zhang, M. (ed.), Academic Press, London, the UK, pp. 373-381. ISBN: 012814565X, 9780128145654.

Rubio, E., Hurtado, S. (2019). 3D food printing technology at home, domestic application, In: Fundamentals of 3D Food Printing and Applications, Godoi, F.C. (ed.), Bhandari, B.R. (ed.), Prakash, S. (ed.), Zhang, M. (ed.), Academic Press, London, 
the UK, pp. 289-329. ISBN: 012814565X, 9780128145654 .

Seo, H.G., Yi, Y.G., Choi, YA, Leigh, J., Yi, Y., Kim, K., Bang, M.S. (2019). Oropharyngeal dysphagia in adults with dyskinetic cerebral palsy and cervical dystonia: A preliminary study. Arch Phys Med Rehabil., 100(3): 495-500. doi: 10.1016/j.apmr.2018.05.024.

Sezer, D., Taş, T.K. (2012). Türkiye'de fonksiyonel gıdaların tüketim araşturmalan, ürün çeşitliliği ve yasal düzenlemeler. Türkiye 11 . Gıda Kongresi, 18 Kasım 2012, Hatay, Türkiye, 41 s.

Shao, LH., Zhao, B., Zhang, Q., Xing, Y., Zhang, K. (2020). 4D printing composite with electrically controlled local deformation. Extreme Mech Lett., 39: 100793. doi: 10.1016/j.eml.2020.100793.

Shellabear, M., Nyrhila, O. (2004). DMLSDevelopment history and state of the art. Proceedings of the Fourth Laser Assisted Net Shape Engineering (LANE), 21-24 September, Erlangen, Germany, 393-404 p.

Southerland, D., Walters, P., Huson, D. (2011). Edible 3D printing. Proceeding of NIP \& Digital Fabrication Conference (7th International), Society for Imaging Science and Technology, 2-6 October, Vol 2, Minneapolis, the USA, 819-822 p.

Sun, J., Peng, Z., Zhou, W., Fuh, J.Y.H., Hong, G.S., Chiu, A. (2015a). A review on 3D printing for customized food fabrication. Procedia Manuf., 1: 308-319. doi: 10.1016/j.promfg.2015.09.057.

Sun,J., Zhou, W., Huang, D., Fuh, J.Y.H., Hong, G.S. (2015b). An overview of 3D printing technologies for food fabrication. Food Bioproc Tech., 8(8): 1605-1615. doi: 10.1007/s11947-0151528-6.

Sun, J., Peng, Z., Yan, L., Fuh., J.Y.H., Hong, G.S. (2015c). 3D food printing-An innovative way of mass customization in food fabrication. Int $J$. Bioprinting, 1(1): 27-38. doi: 10.18063/IJB. 2015.01.006.

Sun, J., Zhou, W., Yan, L., Huang, D., Lin, LY. (2018). Extrusion-based food printing for digitalized food design and nutrition control. $J$.
Food Eng., 220: 1-11. doi: 10.1016/j.jfoodeng.2017.02.028.

Tan, C., Yan Toh, W., Wong, G., Li, L. (2018). Extrusion-based 3D food printing-Materials and machines, Int J. Bioprinting, 4(2): 143. doi: 10.18063/ijb.v4i2.143.

Tao, Y., Do, Y., Yang, H., Lee, YC., Wang, G., Mondoa, C., Cui, J., Wang, W. (2019). Morphlour: Personalized flour-based morphing food induced by dehydration or hydration method. Proceedings of the 32nd Annual ACM Symposium on User Interface Software and Technology, 20-23 October, Louisiana, the USA, 329-340 p.

Terfansky, M., Thangavelu, M., Fritz, B., Khoshnevis, B. (2013). 3D printing of food for space missions. AIAA SPACE 2013 Conference and Exposition, 10-12 September, San Diego, the USA. doi: 10.2514/6.20135346.

Truby, R.L., Lewis, J.A. (2016). Printing soft matter in three dimensions. Nature, 540: 371-378. doi: 10.1038/nature21003.

Vancauwenberghe, V., Delele, M.A., Vanbiervliet, J., Aregawi, W., Verboven, P., Lammertyn, J., Nicolaï, B. (2018). Model-based design and validation of food texture of $3 \mathrm{D}$ printed pectinbased food simulants. J. Food Eng., 231: 72-82. doi: 10.1016/j.jfoodeng.2018.03.010.

Wang, L., Zhang, M., Bhandari, Yang, C. (2018). Investigation on fish surimi gel as promising food material for 3D printing. J. Food Eng., 220: 101108. doi: 10.1016/j.jfoodeng.2017.02.029.

Warner, E.L., Norton, L.T., Mills, T.B. (2019). Comparing the viscoelastic properties of gelatin and different concentrations of kappacarrageenan mixtures for additive manufacturing applications. J. Food Eng., 246: 58-66. doi: 10.1016/j.jfoodeng.2018.10.033.

Whitaker, M. (2014). The history of 3D printing in healthcare. Ann R Coll Surg Engl., 96(7): 228229. doi: 10.1308/147363514X13990346756481.

Wolf, M. (2019). Barilla-backed BluRhapsody to launch 3D pasta printing E-commerce service in 2019. https://thespoon.tech/barilla-backedblurhapsody-to-launch-3d-pasta-printing-e- 
commerce-service-in-2019/ (Accessed: 02 Zhao, H., Wang, J., Ren, X., Li, J., Yang, YL., Jin, October 2020).

X. (2018). Personalized food printing for portrait

Yang, F., Zhang, M., Bhandari, B. (2015). Recent development in 3D food printing. Crit Rev Food Sci images. Comput Graph., 70: 188-197. doi: 10.1016/j.cag.2017.07.012.

Nutr., 57(14): 3145-3153. doi: 10.1080/

10408398.2015.1094732. 